\title{
A Method Based on OWA Operator and Distance Measures for Multiple Attribute Decision Making with 2-Tuple Linguistic Information
}

\author{
Shouzhen ZENG $^{1,2}$, Tomas BALEŽENTIS ${ }^{3}$, Chonghui ZHANG $^{2}$ \\ ${ }^{1}$ College of Computer and Information, Zhejiang Wanli University \\ Ningbo 315100, China \\ ${ }^{2}$ College of Statistics and Mathematics, Zhejiang Gongshang University \\ Hangzhou 310018, China \\ ${ }^{3}$ Vilnius Gediminas Technical University \\ Saulètekio Ave. 11, LT-10223 Vilnius, Lithuania \\ e-mail:zszzxl@163.com,tomas@laei.lt,ufo888833@163.com
}

Received: April 2012; accepted: September 2012

\begin{abstract}
In this paper we develop a new method for 2-tuple linguistic multiple attribute decision making, namely the 2-tuple linguistic generalized ordered weighted averaging distance (2LGOWAD) operator. This operator is an extension of the OWA operator that utilizes generalized means, distance measures and uncertain information represented as 2-tuple linguistic variables. By using 2LGOWAD, it is possible to obtain a wide range of 2-tuple linguistic aggregation distance operators such as the 2-tuple linguistic maximum distance, the 2-tuple linguistic minimum distance, the 2-tuple linguistic normalized Hamming distance (2LNHD), the 2-tuple linguistic weighted Hamming distance (2LWHD), the 2-tuple linguistic normalized Euclidean distance (2LNED), the 2-tuple linguistic weighted Euclidean distance (2LWED), the 2-tuple linguistic ordered weighted averaging distance (2LOWAD) operator and the 2-tuple linguistic Euclidean ordered weighted averaging distance (2LEOWAD) operator. We study some of its main properties, and we further generalize the 2LGOWAD operator using quasi-arithmetic means. The result is the Quasi-2LOWAD operator. Finally we present an application of the developed operators to decision-making regarding the selection of investment strategies.
\end{abstract}

Keywords: distance measure, OWA operator, GOWA operator, 2-tuple linguistic variables, multicriteria decision making.

\section{Introduction}

The ordered weighted averaging (OWA) operator (Yager, 1988) is a well-known aggregation operator that provides a parameterized family of aggregation operators, including the maximum, the minimum, and the average. Since its appearance, the OWA operator has received increasing attention from many authors, and it has been applied across many fields (Ahn, 2009; Baležentis and Baležentis, 2011; Beliakov, 2005; Bordogna and

\footnotetext{
${ }^{*}$ Corresponding author.
} 
Fedrizzi, 1997; Calvo et al., 2002; Fodor et al., 1995; Karayiannis, 2000; Liu et al., 2010; Liu and Zhang, 2011; Liu, 2008; Merigó, 2010; Merigó and Casanovas, 2010a, 2010b, 2010c, 2011a, 2011b; Merigó et al., 2010, 2011; Merigó and Gil-Lafuente, 2010, 2011a, 2011b; Merigó and Wei, 2011; Xu, 2005a; Yager, 1993, 2004, 2010; Zeng and Su, 2011; Zeng, 2011; Zhou and Chen, 2010, 2011). In particular, the OWA operator is very useful for aggregating information in decision making problems.

An interesting extension of the OWA operator is the generalized OWA (GOWA) operator (Yager, 2004) that uses generalized means (Dyckhoff and Pedrycz, 1984) in the OWA operator. The GOWA operator in fact generalizes many situations, including OWA and its particular cases, the ordered weighted geometric (OWG) operator (Xu and $\mathrm{Da}$, 2002), the ordered weighted quadratic averaging (OWQA) operator, and the generalized mean. The GOWA operator can be further generalized by using quasi-arithmetic means (Beliakov, 2005), resulting in the Quasi-OWA operator (Fodor et al., 1995; Karayiannis, 2000) that includes the GOWA operator. Further research on GOWA and Quasi-OWA operators can be found in Beliakov (2005), Calvo et al. (2002), Fodor et al. (1995), Merigó and Casanovas (2010a), Merigó and Gil-Lafuente (2009), Wang and Hao (2006), Zeng and $\mathrm{Su}$ (2012), Zhou and Chen (2010, 2011).

A further interesting extension is the one that uses the OWA operator in distance measures. Recently, motivated by the idea of the OWA operator, Merigó and Gil-Lafuente (2010) introduced a new decision making technique called the ordered weighted averaging distance (OWAD) operator. It is an aggregation operator that uses OWA operator and Hamming distance in the same formulation. The main advantage of this operator is that we are able to underestimate or overestimate the selection process according to the desired degree of optimism (i.e., the degree of orness). Therefore, we are able to provide decision maker with an approach to the optimal choice according to his or her interests. Another advantage of the OWAD is that it provides a parameterized family of distance aggregation operators that ranges from the minimum to the maximum distance. Therefore, they are able to provide a wide range of situations depending on the particular attitude taken by the decision maker in the specific problem considered. Moreover, with the OWAD, it is possible to establish an ideal, though hypothetic, alternative in order to compare it with available options in the decision-making problem. As such, the optimal choice is the alternative closest to the ideal one. Since its introduction, the OWAD operator has been receiving increasing attention. For example, Merigó and Casanovas (2010b) extended this approach by using linguistic variables. Merigó and Casanovas (2010c) also developed a generalization by using induced aggregation operators. Furthermore, they also extended this approach by using the Euclidean distance (2011a) and the Minkowski distance (2011b). Zeng and Su (2011) and Zeng (2011) studied the use of intuitionistic fuzzy sets in the OWAD operator. Merigó and Gil-Lafuente (2011a) developed an application in human resource management and in sport management (Merigó and Gil-Lafuente, 2011b). Yager (2010) generalized it by using norms. Merigó et al. (2011) presented an extension by using similarity measures where the Hamming distance was included as a particular case. Xu and Xia (2011) analyzed the use of hesitant fuzzy sets in the OWAD operator. 
Usually, when using the OWAD operator, it is assumed that the available information is clearly known and can be assessed with exact numbers. However, in the real life, there are many decision situations wherein the information cannot be assessed precisely in a quantitative form but may be in a qualitative one, for example, when evaluating the "comfort" or "design" of a car, terms like "good", "medium", "bad" are usually used, and evaluating a car's speed, terms like "very fast", "fast", "slow" can be used instead of numeric values (Bordogna and Fedrizzi, 1997). Thus, in such situations, the use of linguistic approach is necessary. The use of the fuzzy linguistic approach (Zadeh, 1975) provides a direct way to manage the uncertainty and model the linguistic assessments by means of linguistic variables. In the literature, many aggregation operators and approaches have been developed to solve group decision-making problems with linguistic information. In order to effectively avoid the loss and distortion of information in linguistic information processing process, Herrera and Herrera-Viedma (2000) developed 2-tuple arithmetic average (2TAA) operator, 2-tuple weighted average (2TWA) operator, 2-tuple ordered weighted average (2TOWA) operator and extended 2-tuple weighted average (ET-WA) operator. Herrera et al. (2005) presented a group decision-making process for managing non-homogeneous information. Herrera-Viedma et al. (2005) presented a model of consensus support system to assist the experts in all phases of the consensus reaching process of group decision-making problems with multi-granular linguistic preference relations. Herrera et al. (2008) proposed a fuzzy linguistic methodology to deal with unbalanced linguistic term sets. Wang (2009) presented a 2-tuple fuzzy linguistic evaluation model for selecting appropriate agile manufacturing system in relation to MC production. Wei (2010a) proposed a method for multiple attribute group decisionmaking based on the ET-WG and ET-OWG operators with 2-tuple linguistic information. Wei (2011a) proposed the GRA-based linear-programming methodology for multiple attribute group decision making with 2-tuple linguistic assessment information. Merigó et al. (2010) developed the belief structure-linguistic ordered weighted averaging (BSLOWA), the BS-linguistic hybrid averaging (BS-LHA) and a wide range of particular cases. Liu (2009) presented an approach based on 2-tuple is to solve the hybrid multiple attribute decision making problem with weight information unknown. Wei (2010b) extended the TOPSIS method for 2-tuple linguistic multiple attribute group decision making with incomplete weight information. Wei et al. (2010) developed some models for multiple attribute group decision-making with 2-tuple linguistic assessment information. Wei (2011b) utilized the gray relational analysis method for 2-tuple linguistic multiple attribute group decision-making with incomplete weight information. Xu and Wang (2011) developed some 2-tuple linguistic power aggregation operators. Wang et al. (2009) employed GOWA for intuitionistic fuzzy sets.

The aim of this paper is to present a new method for 2-tuple linguistic multiple attribute decision making based on the OWAD and the GOWA operators. For doing so, we develop the 2-tuple linguistic generalized OWA distance (2LGOWAD) operator. It is an aggregation operator that uses the main characteristics of the GOWA and OWAD operators. It uses generalized means, distance measures and uncertain information represented in the form of 2-tuple linguistic assessment information in the same formulation. With 
this generalization, we obtain a wide range of 2-tuple linguistic aggregation distance operators such as the 2-tuple linguistic maximum distance, the 2-tuple linguistic minimum distance, the 2-tuple linguistic normalized Hamming distance (2LNHD), the 2-tuple linguistic weighted Hamming distance (2LWHD), the 2-tuple linguistic normalized Euclidean distance (2LNED), the 2-tuple linguistic weighted Euclidean distance (2LWED), the 2-tuple linguistic ordered weighted averaging distance (2LOWAD) operator and the 2-tuple linguistic Euclidean ordered weighted averaging distance (2LEOWAD) operator. We study some of its main properties, as well as different families of 2LGOWAD operators, including the median-2LGOWAD, the olympic-2LGOWAD and the centered2LGOWAD.

We present a further generalization of the 2LGOWAD operator by using quasiarithmetic means. We refer to this operator as the Quasi-2LOWAD operator. This generalization includes the 2LGOWAD operator and many other situations. We also develop an application of the new approach in a decision making problem on selection of investments. We demonstrate that depending on the particular type of 2LGOWAD operator used, the results may lead to different decisions.

This paper is organized as follows. In Section 2, we briefly review some basic concepts about linguistic approach, the OWA operator, the OWAD and GOWA operators. Section 3 presents the 2LGOWAD operator. Section 4 analyzes different families of 2LGOWAD operators. Section 5 introduces the Quasi-2LOWAD operator, whereas Section 6 develops a numerical example of the new approach. Finally, in Section 7 draws the main conclusions of the paper.

\section{Preliminaries}

This section briefly reviews the linguistic approach, the OWA operator, the OWAD operator, and the GOWA operator.

\subsection{Linguistic Approach}

Let $S=\left\{s_{0}, s_{1}, \ldots, s_{g}\right\}$ be a linguistic term set with odd cardinality. Any label, $s_{i}$ represents a possible value for a linguistic variable, and it should satisfy the following characteristics:

1. A negation operator: $\operatorname{Neg}\left(s_{i}\right)=s_{j}$, such that $j=g-i$ ( $g$ is the Cardinality).

2. The set is ordered: $s_{i} \leqslant s_{j}$ if and only if $i \leqslant j$. Therefore, there exists a minimization and a maximization operator. For example, a set of nine terms $S$ could be given as follows (Xu and $\mathrm{Da}, 2010 ; \mathrm{Xu}, 2004 ; \mathrm{Xu}, 2006)$ :

$$
\begin{aligned}
S=\left\{s_{0}\right. & =\text { extremely poor } ; s_{1}=\text { very poor } ; s_{2}=\text { poor } \\
s_{3} & =\text { slightly poor } ; s_{4}=\text { fair } ; s_{5}=\text { slightly good } \\
& \left.s_{6}=\text { good } ; s_{7}=\text { very good } ; s_{8}=\text { extremely good }\right\}
\end{aligned}
$$


Herrera and Martínez (2000) developed the 2-tuple fuzzy linguistic representation model based on the concept of symbolic translation. It is used for representing the linguistic assessment information by means of a 2-tuple $\left(s_{i}, \alpha_{i}\right)$, where $s_{i}$ is a linguistic label from predefined linguistic term set $S$ and $\alpha_{i}$ is the value of symbolic translation, and $\alpha_{i} \in[-0.5,0.5)$.

DEFINITION 1 (Herrera and Martínez, 2000). Let $\beta$ be the result of an aggregation of the indexes of a set of labels assessed in a linguistic term set $S$, i.e., the result of a symbolic aggregation operation. $\beta \in[0, g]$, being $g$ the cardinality of $S$. Let $i=\operatorname{round}(\beta)$ and $\alpha=\beta-i$ be two values such that $i \in[0, g]$ and $\alpha \in[-0.5,0.5)$, then $\alpha$ is called a symbolic translation.

Definition 2 (Herrera and Martínez, 2000). Let $S=\left\{s_{0}, s_{1}, \ldots, s_{g}\right\}$ be a linguistic term set and $\beta \in[0, g]$ be a value representing the result of a symbolic aggregation operation, then the 2-tuple that expresses the equivalent information to $\beta$ is obtained with the following function:

$$
\begin{aligned}
& \Delta:[0, g] \rightarrow S \times[-0.5,0.5), \\
& \Delta(\beta)=\left(s_{i}, \alpha_{i}\right), \quad \text { with }\left\{\begin{array}{l}
s_{i}, \quad i=\operatorname{round}(\beta), \\
\alpha_{i}=\beta-i, \quad \alpha_{i} \in[-0.5,0.5) .
\end{array}\right.
\end{aligned}
$$

where round $(\cdot)$ is the usual round operation, $s_{i}$ has the closest index label to $\beta$ and $\alpha_{i}$ is the value of the symbolic translation.

Definition 3 (Herrera and Martínez, 2000). Let $S=\left\{s_{0}, s_{1}, \ldots, s_{g}\right\}$ be a linguistic term set and $\left(s_{i}, \alpha_{i}\right)$ be a 2-tuple. There is always a function $\Delta^{-1}$ can be defined, such that, from a 2-tuple $\left(s_{i}, \alpha_{i}\right)$ it return its equivalent numerical value $\beta \in[0, g]$, which is

$$
\begin{aligned}
& \Delta^{-1}: S \times[-0.5,0.5) \rightarrow[0, g], \\
& \Delta^{-1}\left(s_{i}, \alpha_{i}\right)=i+\alpha_{i}=\beta .
\end{aligned}
$$

From Definitions 1 and 2, we can conclude that the conversion of a linguistic term into a linguistic 2-tuple consists of adding a value 0 as symbolic translation: $\Delta\left(s_{i}\right)=\left(s_{i}, 0\right)$.

Definition 4 (Herrera and Martínez, 2000). Let $a=\left(s_{k}, \alpha_{k}\right)$ and $b=\left(s_{l}, \alpha_{l}\right)$ be two 2-tuples, they should have the following properties:

1. If $k<l$, then $a<b$.

2. If $k=l$, then
(a) If $\alpha_{k}=\alpha_{l}$, then $a=b$;
(b) If $\alpha_{k}<\alpha_{l}$, then $a<b$;
(c) If $\alpha_{k}>\alpha_{l}$, then $a>b$. 
Different approaches have been suggested for dealing with 2-tuple linguistic information (Baležentis and Baležentis, 2011; Cabrerizo et al., 2005; Herrera and HerreraViedma, 2000; Herrera et al., 2008; Liu, 2009; Merigó et al., 2010; Wang and Hao, 2006; Wei, 2010a; Xu, 2005b). In order to measure the deviation between 2-tuple linguistic variables, Liu (2009) defined a linguistic distance as follows.

DEFinition 5. Let $\left(s_{k}, \alpha_{k}\right)$ and $\left(s_{l}, \alpha_{l}\right)$ be two 2-tuple linguistic variables, then

$$
d\left(\left(s_{k}, \alpha_{k}\right),\left(s_{l}, \alpha_{l}\right)\right)=\frac{\left|\left(k+\alpha_{k}\right)-\left(l+\alpha_{l}\right)\right|}{g}
$$

is called a distance between 2-tuple linguistic $\left(s_{k}, \alpha_{1}\right)$ and $\left(s_{l}, \alpha_{2}\right)$.

\subsection{The OWA Operator}

The OWA operator (Yager, 1988) provides a parameterized family of aggregation operators that include the maximum, the minimum and the average criteria as special cases. This operator can be defined as follows.

DEFINITION 6. An OWA operator of dimension $n$ is a mapping OWA: $R^{n} \rightarrow R$ that has an associated weighting $W$ with $w_{j} \in[0,1]$ and $\sum_{j=1}^{n} w_{j}=1$ such that:

$$
\operatorname{OWA}\left(a_{1}, a_{2}, \ldots, a_{n}\right)=\sum_{j=1}^{n} w_{j} b_{j}
$$

where $b_{j}$ is the $j$ th largest of the $a_{i}$.

\subsection{The GOWA Operator}

The generalized OWA (GOWA) operator (Fodor et al., 1995; Karayiannis, 2000) generalizes a wide range of aggregation operators that includes the OWA operator with its particular cases, the OWG operator, the ordered weighted harmonic averaging (OWHA) operator and the OWQA operator. It can be defined as follows.

DEFINITION 7. A GOWA operator of dimension $n$ is a mapping GOWA: $R^{n} \rightarrow R$ that has an associated weighting $W$ with $w_{j} \in[0,1]$ and $\sum_{j=1}^{n} w_{j}=1$ such that:

$$
\operatorname{GOWA}\left(a_{1}, a_{2}, \ldots, a_{n}\right)=\left(\sum_{j=1}^{n} w_{j} b_{j}^{\lambda}\right)^{1 / \lambda}
$$

where $b_{j}$ is the $j$ th largest of the $a_{i}$, and $\lambda$ is a parameter such that $\lambda \in(-\infty,+\infty)$.

Note that it is possible to distinguish between descending (DGOWA) and ascending (AGOWA) orders. The GOWA operator is commutative, monotonic, bounded and idempotent. It can also be demonstrated that it has as special cases the maximum, the minimum 
and the generalized mean. If we look to different values of the parameter $\lambda$, we can also obtain other special cases such as the usual OWA operator, the geometric OWA (OWGA) operator and the quadratic OWA (OWQA) operator.

\subsection{The OWAD Operator}

Recently, Merigó and Gil-Lafuente (2010) introduced a new index for decision making using the OWA operator to calculate Hamming distance called the ordered weighted averaging distance (OWAD) operator. For two sets $A=\left\{a_{1}, a_{2}, \ldots, a_{n}\right\}$ and $B=$ $\left\{b_{1}, b_{2}, \ldots, b_{n}\right\}$, the OWAD operator can be defined as follows.

DEFINITION 8. An OWAD operator of dimension $n$ is a mapping OWAD: $R^{n} \times R^{n} \rightarrow R$ that has an associated weighting $W$ with $w_{j} \in[0,1]$ and $\sum_{j=1}^{n} w_{j}=1$ such that:

$$
\operatorname{OWAD}\left(\left\langle a_{1}, b_{1}\right\rangle,\left\langle a_{2}, b_{2}\right\rangle, \ldots,\left\langle a_{n}, b_{n}\right\rangle\right)=\sum_{j=1}^{n} w_{j} d_{j},
$$

where $d_{j}$ is the $j$ th largest of the $\left|a_{i}-b_{i}\right|$.

The OWAD operator is commutative, monotonic, bounded and idempotent. This distance operator provides a parameterized family of aggregation operators ranging from the minimum to the maximum distance.

When using the OWAD operator, it is assumed that the available information includes exact numbers or crisp numbers. In the following, we shall develop the 2-tuple linguistic generalized ordered weighted averaging distance (2LGOWAD) operator.

\section{The 2LGOWAD Operator}

The 2-tuple linguistic generalized ordered weighted averaging distance (2LGOWAD) operator is an extension of the OWAD operator that uses generalized means and 2-tuple linguistic variables in the aggregation. The 2LGOWAD provides a model that is able to assess the information in situations with high degree of uncertainty by using 2-tuple linguistic variables. Moreover, by using the generalized means, we obtain a generalization that includes a wide range of 2-tuple linguistic aggregation distance operators, such as the 2-tuple linguistic maximum distance, the 2-tuple linguistic minimum distance, the 2LNHD, 2LWHD, 2LNED, 2LWED, 2LOWAD and 2LEOWAD operators. It can be defined as follows.

DEFinition 9. Let $X=\left\{x_{i} \mid x_{i}=\left(s_{x_{i}}, \alpha_{x_{i}}\right), i=1,2, \ldots, n\right\}$ and $Y=\left\{y_{i} \mid y_{i}=\right.$ $\left.\left(s_{y_{i}}, \alpha_{y_{i}}\right), i=1,2, \ldots, n\right\}\left(s_{x_{i}}, s_{y_{i}} \in S, \alpha_{x_{i}}, \alpha_{y_{i}} \in[-0.5,0.5), i \in N\right)$ be two sets of linguistic 2-tuples, then the 2-tuple linguistic generalized ordered weighted averaging 
distance (2LGOWAD) operator can be defined as follows:

$$
\operatorname{2LGOWAD}\left(\left(x_{1}, y_{1}\right), \ldots,\left(x_{n}, y_{n}\right)\right)=\left(\sum_{j=1}^{n} w_{j} d_{j}^{\lambda}\right)^{1 / \lambda}
$$

where $w_{j}$ is the weighting vector such that $w_{j} \in[0,1]$ and $\sum_{j=1}^{n} w_{j}=1, d_{j}$ is the $j$ th largest of the $d\left(x_{i}, y_{i}\right)$ and $d\left(x_{i}, y_{i}\right)$ is the argument variable represented in the form of distance defined by (6), and $\lambda$ is a parameter such that $\lambda \in(-\infty,+\infty)$.

EXAMPLE 1. Let $S$ be a linguistic term set defined by (1), $X=\left\{x_{1}, x_{2}, x_{3}, x_{4}\right\}=$ $\left\{\left(s_{1}, \alpha_{0.2}\right),\left(s_{4}, \alpha_{0.4}\right),\left(s_{5}, \alpha_{-0.2}\right),\left(s_{6}, \alpha_{0}\right)\right\}$ and $Y=\left\{y_{1}, y_{2}, y_{3}, y_{4}\right\}=\left\{\left(s_{4}, \alpha_{0.3}\right)\right.$, $\left.\left(s_{4}, \alpha_{-0.4}\right),\left(s_{7}, \alpha_{-0.3}\right),\left(s_{2}, \alpha_{0.2}\right)\right\}$ be two sets of linguistic 2-tuples, then $d\left(x_{1}, y_{1}\right)=$ $d\left(\left(s_{1}, \alpha_{0.2}\right),\left(s_{4}, \alpha_{0.3}\right)\right)=\frac{|(1+0.2)-(4+0.3)|}{8}=0.388$. Similarly, we have $d\left(x_{2}, y_{2}\right)=$ $0.1, d\left(x_{3}, y_{3}\right)=0.238, d\left(x_{4}, y_{4}\right)=0.475$.

Assume the following weighting vector $W=(0.3,0.2,0.4,0.1)$ and without loss of generality, let $\lambda=2$, if we calculate the distance between $X$ and $Y$ by using the 2LGOWAD operator, then we have:

$$
\begin{aligned}
2 \operatorname{LGOWAD}(X, Y)=( & 0.3 \times 0.475^{2}+0.2 \times 0.388^{2}+0.4 \times 0.238^{2} \\
& \left.+0.1 \times 0.1^{2}\right)^{1 / 2}=0.349
\end{aligned}
$$

From a generalized perspective of the reordering step, we can distinguish between the descending 2LGOWAD (D2LGOWAD) operator and the ascending 2LGOWAD (A2LGOWAD) operator by using $w_{j}=w_{n-j+1}^{*}$, where $w_{j}$ is the $j$ th weight of the D2LGOWAD and $w_{n-j+1}^{*}$ the $j$ th weight of the A2LGOWAD operator.

In the following, we shall study some desirable properties of the 2LGOWAD operator.

Theorem 1 (Commutativity). If $f$ is the $2 L G O W A D$ operator, then

$$
f\left(\left(x_{1}, y_{1}\right), \ldots,\left(x_{n}, y_{n}\right)\right)=f\left(\left(u_{1}, v_{1}\right), \ldots,\left(u_{n}, v_{n}\right)\right)
$$

where $\left(\left(u_{1}, v_{1}\right), \ldots,\left(u_{n}, v_{n}\right)\right)$ is any permutation of the arguments $\left(\left(x_{1}, y_{1}\right), \ldots,\left(x_{n}, y_{n}\right)\right)$.

Theorem 2 (Monotonicity). Assume $f$ is the 2LGOWAD operator, if $d\left(x_{i}, y_{i}\right) \geqslant$ $d\left(x_{i}^{\prime}, y_{i}^{\prime}\right)$ for all $i$, then

$$
f\left(\left(x_{1}, y_{1}\right), \ldots,\left(x_{n}, y_{n}\right)\right) \geqslant f\left(\left(x_{1}^{\prime}, y_{1}^{\prime}\right), \ldots,\left(x_{n}^{\prime}, y_{n}^{\prime}\right)\right)
$$

Theorem 3 (Boundedness). Assume $f$ is the 2LGOWAD operator, then

$$
\min _{i}\left(d\left(x_{i}, y_{i}\right)\right) \leqslant f\left(\left(x_{1}, y_{1}\right), \ldots,\left(x_{n}, y_{n}\right)\right) \leqslant \max _{i}\left(d\left(x_{i}, y_{i}\right)\right)
$$


Theorem 4 (Idempotency). Assume $f$ is the $2 L G O W A D$ operator, if $d\left(x_{i}, y_{i}\right)=$ a for all $i$, then

$$
f\left(\left(x_{1}, y_{1}\right), \ldots,\left(x_{n}, y_{n}\right)\right)=a
$$

\section{Families of 2LGOWAD Operators}

By choosing a different manifestation of the weighting vector and the parameter $\lambda$ in the 2LGOWAD operator, we are able to obtain different types of 2-tuple linguistic aggregation distance operators.

REMARK 1 . When $\lambda=1$, the 2LGOWAD operator becomes the 2LOWAD operator.

$$
\operatorname{LLGOWAD}\left(\left(x_{1}, y_{1}\right), \ldots,\left(x_{n}, y_{n}\right)\right)=\sum_{j=1}^{n} w_{j} d_{j}
$$

REMARK 2. When $\lambda \rightarrow 0$, we form the 2LOWGD operator.

$$
2 \operatorname{LGOWAD}\left(\left(x_{1}, y_{1}\right), \ldots,\left(x_{n}, y_{n}\right)\right)=\prod_{j=1}^{n} d_{j}^{w_{j}}
$$

REMARK 3. When $\lambda=-1$, we get the 2LOWHAD operator.

$$
2 \operatorname{LGOWAD}\left(\left(x_{1}, y_{1}\right), \ldots,\left(x_{n}, y_{n}\right)\right)=\frac{1}{\sum_{j=1}^{n} \frac{w_{j}}{d_{j}}} .
$$

REMARK 4. When $\lambda=2$, we get the 2LEOWAD operator.

$$
2 \operatorname{LGOWAD}\left(\left(x_{1}, y_{1}\right), \ldots,\left(x_{n}, y_{n}\right)\right)=\left(\sum_{j=1}^{n} w_{j} d_{j}^{2}\right)^{1 / 2}
$$

Note that in all these cases, if $w_{j}=1 / n$, we get the 2-tuple linguistic average situation such as the 2-tuple linguistic normalized Hamming distance (2LNHD) and the 2-tuple linguistic normalized Euclidean distance (2LNED), and if the ordered position of $d_{j}$ is the same than the position of $d\left(x_{i}, y_{i}\right)$, we get the 2-tuple linguistic weighted average type including the 2-tuple linguistic weighted Hamming distance (2LWHD) and the 2tuple linguistic weighted Euclidean distance (2LWED).

Note that other families could be obtained by using different values in the parameter $\lambda$. Especially, we find the 2-tuple linguistic maximum distance when $\lambda \rightarrow \infty$ and the 2-tuple linguistic minimum distance when $\lambda \rightarrow-\infty$.

REMARK 5. If we analyse the weighting vector, then, we find the following cases: 
- The 2-tuple linguistic maximum distance $\left(w_{1}=1\right.$ and $w_{j}=0$, for all $\left.j \neq 1\right)$.

- The 2-tuple linguistic minimum distance $\left(w_{n}=1\right.$ and $w_{j}=0$, for all $\left.j \neq n\right)$.

- The 2-tuple linguistic generalized distance $\left(w_{j}=1 / n\right.$ for all $\left.j\right)$.

- The step-2LGOWAD operator $\left(w_{k}=1\right.$ and $w_{j}=0$, for all $j \neq k$ ).

- The centered-2LGOWAD operator (if it is symmetric, strongly decaying from the center to the maximum and the minimum, and inclusive).

- The olympic-2LGOWAD operator $\left(w_{1}=w_{n}=0\right.$ and for all others $w_{j}=1 /$ $(n-2))$.

- The median-2LGOWAD operator (if $n$ is odd we assign $w_{(n+1) / 2}=1$ and $w_{j}=0$ for all others. If $n$ is even, then we assign $\left.w_{n / 2}=w_{(n / 2)+1}=0.5\right)$.

- Etc.

REMARK 6. We could develop a lot of other families of 2LGOWAD weights in a similar way as it has been developed in a lot of studies (Merigó and Casanovas, 2010a, 2010b, 2011b; Merigó and Gil-Lafuente, 2010; Merigó et al. 2011; Xu and Chen, 2008; Zeng and $\mathrm{Su}, 2011$ ).

\section{Quasi-2LOWAD Operators}

The 2LGOWAD can be generalized by using quasi-arithmetic means in a similar way as it was done by Fodor et al. (1995), Merigó and Casanovas (2010a, 2011b). We call it the Quasi-2LOWAD operator. Its main advantage is that it provides a more general formulation because it includes the 2LGOWAD operator as a particular case. It can be defined as follows.

DEFINITION 10. Let $\hat{S}$ be a 2-tuple linguistic set. A Quasi-2LOWAD operator of dimension $n$ is a mapping $Q 2 L O W A D: \hat{S}^{n} \times \hat{S}^{n} \rightarrow R$ that has an associated weighting vector $W$ of dimension $n$ such that the sum of the weights is 1 and $w_{j} \in[0,1]$, then:

$$
\text { Q2LOWAD }\left(\left(x_{1}, y_{1}\right), \ldots,\left(x_{n}, y_{n}\right)\right)=g^{-1}\left(\sum_{j=1}^{n} w_{j} g\left(d_{j}\right)\right) \text {, }
$$

where $d_{j}$ is the $j$ th largest of the $d\left(x_{i}, y_{i}\right)$ and $d\left(x_{i}, y_{i}\right)$ is the argument variable represented in the form of distance defined by (6), and $g$ is a general continuous strictly monotonic function.

Analyzing the reordering step, we also find that the weights of the ascending and descending versions are related by $w_{j}=w_{n-j+1}^{*}$, where $w_{j}$ is the $j$ th weight of the QD2LOWAD and $w_{n-j+1}^{*}$ is the $j$ th weight of the QA2LOWAD operator. As we can see, the 2LGOWAD operator is a particular case of the Q2LOWAD when $g\left(d_{j}\right)=d_{j}^{\lambda}$. Note that all the properties and particular cases discussed with respect to the 2LGOWAD operator also subject to this generalization. Thus, we could analyze a wide range 
of families of Quasi-2LOWAD operators, including the Quasi-olympic-Quasi-2LOWAD, the Quasi-S-Quasi-2LOWAD, and the Quasi-median-Quasi-2LOWAD. Note also that the Quasi-2LOWAD operator includes many other situations such as the exponential-Quasi2LOWAD and the radical-Quasi-2LOWAD.

\section{Decision Making with the 2LGOWAD Operator}

In the following, we present a numerical example of the new approach in a decision making problem. We study a problem of investment selection where a decision maker is looking for the optimal strategy. We analyze different particular cases of the 2LGOWAD operator such as the 2LNHD, the 2LNED, the 2LOWAD and the 2LEOWAD. Note that with this analysis, we obtain "optimal" choices that depend on the aggregation operator used in each particular case. Then, we see that each aggregation operator may lead to different results and decisions. The main advantage of the 2LGOWAD is that it includes a wide range of particular cases, reflecting different potential factors to be considered in the decision making problem depending on the situation found in the analysis. Thus, the decision maker is able to consider a lot of possibilities and select the aggregation operator that is in closest accordance with his interests.

Assume that a company wants to invest some money in a region. Initially, they consider five possible investment alternatives.

- $A_{1}=$ Invest in the European market.

- $A_{2}=$ Invest in the American market.

- $A_{3}=$ Invest in the Asian market.

- $A_{4}=$ Invest in the African market.

- $A_{5}=$ Do not invest money.

In order to evaluate these investments, the investor has brought together a group of experts. This group considers that each investment alternative can be described with the following characteristics:

- $C_{1}=$ Benefits in the short term.

- $C_{2}=$ Benefits in the mid term.

- $C_{3}=$ Benefits in the long term.

- $C_{4}=$ Risk of the investment.

- $C_{5}=$ Other variables.

Due to the fact that the general characteristics are very imprecise because they contain a lot of particular aspects, the experts cannot use numerical values in the analysis. Instead, they use linguistic variables to evaluate the general results obtained for each candidate depending on the characteristic considered. In order to do so, they establish the following linguistic scale.

$$
\begin{aligned}
S=\left\{s_{0}\right. & =\text { extremely poor; } s_{1}=\text { very poor } ; s_{2}=\text { poor } \\
& s_{3}=\text { slightly poor; } s_{4}=\text { fair } ; s_{5}=\text { slightly good } \\
& \left.s_{6}=\text { good } ; s_{7}=\text { very good } ; s_{8}=\text { extremely good }\right\}
\end{aligned}
$$


Table 1

Available investment strategies

\begin{tabular}{llllll}
\hline & $C_{1}$ & $C_{2}$ & $C_{3}$ & $C_{4}$ & $C_{5}$ \\
\hline$A_{1}$ & $\left(s_{6}, \alpha_{0.2}\right)$ & $\left(s_{5}, \alpha_{0.3}\right)$ & $\left(s_{4}, \alpha_{0.3}\right)$ & $\left(s_{3}, \alpha_{0.2}\right)$ & $\left(s_{5}, \alpha_{0.1}\right)$ \\
$A_{2}$ & $\left(s_{4}, \alpha_{-0.2}\right)$ & $\left(s_{4}, \alpha_{0}\right)$ & $\left(s_{6}, \alpha_{0.1}\right)$ & $\left(s_{2}, \alpha_{0.4}\right)$ & $\left(s_{5}, \alpha_{0.2}\right)$ \\
$A_{3}$ & $\left(s_{4}, \alpha_{0.1}\right)$ & $\left(s_{3}, \alpha_{-0.2}\right)$ & $\left(s_{5}, \alpha_{-0.3}\right)$ & $\left(s_{1}, \alpha_{0.2}\right)$ & $\left(s_{4}, \alpha_{0.1}\right)$ \\
$A_{4}$ & $\left(s_{5}, \alpha_{-0.2}\right)$ & $\left(s_{3}, \alpha_{0.1}\right)$ & $\left(s_{6}, \alpha_{0}\right)$ & $\left(s_{3}, \alpha_{0.4}\right)$ & $\left(s_{7}, \alpha_{0.2}\right)$ \\
$A_{5}$ & $\left(s_{2}, \alpha_{0.2}\right)$ & $\left(s_{5}, \alpha_{0.2}\right)$ & $\left(s_{3}, \alpha_{-0.2}\right)$ & $\left(s_{5}, \alpha_{0.1}\right)$ & $\left(s_{4}, \alpha_{0.3}\right)$ \\
\hline
\end{tabular}

Table 2

Ideal investment strategy

\begin{tabular}{|c|c|c|c|c|c|}
\hline & $C_{1}$ & $C_{2}$ & $C_{3}$ & $C_{4}$ & $C_{5}$ \\
\hline$I$ & $\left(s_{7}, \alpha_{0.2}\right)$ & $\left(s_{6}, \alpha_{0.3}\right)$ & $\left(s_{7}, \alpha_{0.2}\right)$ & $\left(s_{6}, \alpha_{0.3}\right)$ & $\left(s_{7}, \alpha_{0.4}\right)$ \\
\hline
\end{tabular}

Table 3

Aggregated results

\begin{tabular}{lllllllll}
\hline & Max & Min & 2LNHD & 2LNED & 2LWHD & 2LWED & 2LOWAD & 2LEOWAD \\
\hline$A_{1}$ & 0.388 & 0.125 & 0.258 & 0.281 & 0.274 & 0.293 & 0.231 & 0.256 \\
$A_{2}$ & 0.488 & 0.138 & 0.323 & 0.345 & 0.308 & 0.329 & 0.288 & 0.312 \\
$A_{3}$ & 0.634 & 0.288 & 0.413 & 0.431 & 0.403 & 0.423 & 0.378 & 0.392 \\
$A_{4}$ & 0.4 & 0.025 & 0.248 & 0.284 & 0.22 & 0.268 & 0.21 & 0.255 \\
$A_{5}$ & 0.625 & 0.138 & 0.37 & 0.421 & 0.346 & 0.381 & 0.321 & 0.374 \\
\hline
\end{tabular}

After careful analysis of these characteristics, the experts have given the following information shown in Table1. Note that the results are linguistic values represented with the 2-tuple linguistic approach.

The experts establish the values of an ideal investment as it is shown in Table 2. This ideal investment represents the optimal results for the company.

In this problem, the group of experts considers that the general attitudinal character of the company is given by the following weighting vector: $W=(0.1,0.2,0.2,0.2,0.3)$. With this information, it is possible to aggregate the available information in order to take a decision. The method consists in comparing the available investments with the ideal one by using the 2LGOWAD operator and its particular cases. The results are shown in Table 3.

As we can see, for most of the cases the best alternative is $A_{4}$ because it seems to be the one with the lowest distance to the ideal investment strategy. However, for some particular situations, we may find another optimal choice. Therefore, it is of interest to establish an ordering of the investments for each particular case. Note that the best choice is the one with the lowest distance. The results are shown in Table 4. 
Table 4

Ordering of the investment strategies

\begin{tabular}{llll}
\hline & Ordering & Ordering \\
\hline Max & $A_{1} \succ A_{4} \succ A_{2} \succ A_{5} \succ A_{3}$ & 2LWHD & $A_{4} \succ A_{1} \succ A_{2} \succ A_{5} \succ A_{3}$ \\
Min & $A_{4} \succ A_{1} \succ A_{2} \succ A_{5} \succ A_{3}$ & 2LWED & $A_{4} \succ A_{1} \succ A_{2} \succ A_{5} \succ A_{3}$ \\
2LNHD & $A_{4} \succ A_{1} \succ A_{2} \succ A_{5} \succ A_{3}$ & 2LOWAD & $A_{4} \succ A_{1} \succ A_{2} \succ A_{5} \succ A_{3}$ \\
2LNED & $A_{1} \succ A_{4} \succ A_{2} \succ A_{5} \succ A_{3}$ & 2LEOWAD & $A_{4} \succ A_{1} \succ A_{2} \succ A_{5} \succ A_{3}$ \\
\hline
\end{tabular}

As we can see, depending on the aggregation operator used, the ordering of the investment strategies may be different. Therefore, the decision concerning which investment strategy select may be also different.

\section{Conclusions}

We have presented the 2LGOWAD operator as an aggregation operator that uses the main characteristics of the GOWA and OWAD operators. We analyzed it as an extension of the OWAD operator that uses generalized means and uncertain information represented in the form of 2-tuple linguistic variables. This operator is very useful because it generalizes the GOWA operator for uncertain situations in which it is not possible to use exact numbers. Moreover, it includes many different types of 2-tuple linguistic aggregation distance operators, such as the 2LNHD, the 2LNED, the 2LWHD, the 2LWED, the 2LOWAD and 2LEOWAD operators.

We have also introduced the Quasi-2LOWAD operator. This operator is a further generalization of the 2LGOWAD operator that includes the use of quasi-arithmetic means. This generalization is more complete because it includes the 2LGOWAD operator as a special type as well as many other operators.

We have presented an application of this new approach to a decision making problem regarding the selection of investment strategies. The main advantage of the 2LGOWAD operator is that it makes it possible to consider a wide range of situations depending on the interests of the decision maker. Depending on the particular operator used, the results and decisions may be different.

In future research, we expect to develop further generalizations by considering other types of the GOWA operator and applying them to other decision making problems. Particularly, the hybrid multi-criteria decision making methods (Fouladgar et al., 2012a, 2012b; Ginevičius et al., 2012) are to be developed and employed.

Acknowledgements. This paper is supported by the Philosophy and Social Science Planning Projects of Zhejiang (No. 12YD66YB), National Funds of Social Science of China (No. 12ATJ001) and Zhejiang Province Natural Science Foundation (No. Y6110777, No. LQ12G03010). 


\section{References}

Ahn, B.S. (2009). Some remarks on the LSOWA approach for obtaining OWA operator weights. International Journal of Intelligent Systems, 24, 1265-1279.

Baležentis, A., Baležentis, T. (2011). An innovative multi-criteria supplier selection based on two-tuple MULTIMOORA and hybrid data. Economic Computation and Economic Cybernetics Studies and Research, 45(2), 37-56.

Beliakov, G. (2005). Learning weights in the generalized OWA operators. Fuzzy Optimization and Decision Making, 4, 119-130.

Bordogna, G., Fedrizzi, M. (1997). A linguistic modeling of consensus in group decision making based on OWA operators. IEEE Transactions on Systems, Man and Cybernetics. Part A, Systems and Humans, 27, 126-132.

Cabrerizo, F.J., Alonso, S., Herrera-Viedma, E. (2009). A consensus model for group decision making problems with unbalanced fuzzy linguistic information. International Journal of Information Technology and Decision Making, 8, 109-131.

Calvo, T., Mayor, G., Mesiar, R. (2002). Aggregation Operators: New Trends and Applications. Physica-Verlag, New York.

Dyckhoff, H., Pedrycz, W. (1984). Generalized means as a model of compensative connectives. Fuzzy Sets and Systems, 14, 143-154.

Fodor, J., Marichal, J.L., Roubens, M. (1995). Characterization of the ordered weighted averaging operators. IEEE Transactions on Fuzzy Systems, 3, 236-240.

Fouladgar, M.M., Yazdani-Chamzini, A., Lashgari, A., Zavadskas, E.K., Turskis, Z. (2012b). Maintenance strategy selection using AHP and COPRAS under fuzzy environment. International Journal of Strategic Property Management, 16(1), 85-104.

Fouladgar, M.M., Yazdani-Chamzini, A., Zavadskas, E.K., Haji Moini, S.H. (2012a). A new hybrid model for evaluating the working strategies: case study of construction company. Technological and Economic Development of Economy, 18(1), 164-188.

Ginevičius, R., Podvezko, V., Novotny, M., Komka, A. (2012). Comprehensive quantitative evaluation of the strategic potential of an enterprise. Economic Computation and Economic Cybernetics Studies and Research, 46(1), 153-168.

Herrera, F., Martínez, L. (2000). A 2-tuple fuzzy linguistic representation model for computing with words. IEEE Transactions on Fuzzy Systems, 8, 746-752.

Herrera, F., Herrera-Viedma, E. (2000). Choice functions and mechanisms for linguistic preference relations. European Journal of Operational Research, 120, 144-161.

Herrera, F., Herrera-Viedma, E., Martínez, L. (2008). A fuzzy linguistic methodology to deal with unbalanced linguistic term sets. IEEE Transactions on Fuzzy Systems, 16, 354-370.

Herrera, F., Martínez, L., Sánchez, P.J. (2005). Managing non-homogeneous information in group decision making. European Journal of Operational Research, 166, 115-132.

Herrera-Viedma, E., Martinez, L., Mata, F., Chiclana, F. (2005). A consensus support system model for group decision-making problems with multigranular linguistic preference relations. IEEE Transactions on Fuzzy Systems, 13, 644-658.

Karayiannis, N. (2000). Soft learning vector quantization and clustering algorithms based on ordered weighted aggregation operators. IEEE Transactions on Neural Networks, 11, 1093-1105.

Liu, J.W., Cheng, C.H., Chen, Y.H., Chen, T.L. (2010). OWA rough set model for forecasting the revenues growth rate of the electronic industry. Expert Systems with Applications, 37, 610-617.

Liu, P.D. (2009). A novel method for hybrid multiple attribute decision making. Knowledge-Based Systems, 22, $388-391$.

Liu, P.D., Zhang, X. (2011). Investigation into evaluation of agriculture informatization level based on twotuple. Technological and Economic Development of Economy, 17(1), 74-86.

Liu, X. (2008). A general model of parameterized OWA aggregation with given orness level. International Journal of Approximate Reasoning, 48, 598-627.

Merigó, J.M. (2010). Fuzzy decision making with immediate probabilities. Computers \& Industrial Engineering, 58, 651-657.

Merigó, J.M., Casanovas, M. (2010a). The fuzzy generalized OWA operator and its application in strategic decision making. Cybernetics \& Systems, 41, 359-370. 
Merigó, J.M., Casanovas, M. (2010b). Decision making with distance measures and linguistic aggregation operators. International Journal of Fuzzy Systems, 12, 190-198.

Merigó, J.M., Casanovas, M. (2010c). Decision making with distance measures and induced aggregation operators. Computers \& Industrial Engineering, 60, 66-76.

Merigó, J.M., Casanovas, M. (2011a). Induced aggregation operators in the Euclidean distance and its application in financial decision making. Expert Systems with Applications, 38, 7603-7608.

Merigó, J.M., Casanovas, M. (2011b). A new Minkowski distance based on induced aggregation operators. International Journal of Computational Intelligence Systems, 4, 123-133.

Merigó, J.M., Gil-Lafuente, A.M. (2009). The induced generalized OWA operator. Information Sciences, 179, 729-741.

Merigó, J.M., Gil-Lafuente, A.M. (2010). New decision making techniques and their application in the selection of financial products. Information Sciences, 180, 2085-2094.

Merigó, J.M., Gil-Lafuente, A.M. (2011a). Decision-making in sport management based on the OWA operator. Expert Systems with Applications, 38, 10408-10413.

Merigó, J.M., Gil-Lafuente, A.M. (2011b). OWA operators in human resource management. Economic Computation and Economic Cybernetics Studies and Research, 45, 153-168.

Merigó, J.M., Wei, G.W. (2011). Probabilistic aggregation operators and their application in uncertain multiperson decision making. Technological and Economic Development of Economy, 17, 335-351.

Merigó, J.M., Gil-Lafuente, A.M., Gil-Aluja, J. (2011). Decision making with the induced generalized adequacy coefficient. Applied and Computational Mathematics, 2, 321-339.

Merigó, J.M., Casanovas, M., Martínez, L. (2010). Linguistic aggregation operators for linguistic decision making based on the Dempster-Shafer theory of evidence. International Journal of Uncertainty, Fuzziness and Knowledge-Based Systems, 18, 287-304.

Wang, W.P. (2009). Evaluating new product development performance by fuzzy linguistic computing. Expert Systems with Applications, 36, 9759-9766.

Wang, J.H., Hao, J. (2006). A new version of 2-tuple fuzzy linguistic representation model for computing with words. IEEE Transactions on Fuzzy Systems, 14, 435-445.

Wang, S.Q., Li, D.F., Wu, Z.Q. (2009). Generalized ordered weighted averaging operators based methods for MADM in intuitionistic Fuzzy setting. Journal of Systems Engineering and Electronics, 20, 1247-1254.

Wei, G.W. (2010a). A method for multiple attribute group decision making based on the ET-WG and ET-OWG operators with 2-tuple linguistic information. Expert Systems with Applications, 37, 7895-7900.

Wei, G.W. (2010b). Extension of TOPSIS method for 2-tuple linguistic multiple attribute group decision making with incomplete weight information. Knowledge and Information Systems, 25, 623-634.

Wei, G.W. (2011a). GRA-based linear-programming methodology for multiple attribute group decision making with 2-tuple linguistic assessment information. Information: An International Interdisciplinary Journal, 14, $1105-1110$.

Wei, G.W. (2011b). Grey relational analysis method for 2-tuple linguistic multiple attribute group decision making with incomplete weight information. Expert Systems with Applications, 38, 4824-4828.

Wei, G.W., Lin, R., Zhao, X.F., Wang, H.J. (2010). Models for multiple attribute group decision making with 2-tuple linguistic assessment information. International Journal of Computational Intelligence Systems, 3, $315-324$.

Xu, Z.S. (2004). EOWA and EOWG operators for aggregating linguistic labels based on linguistic preference relations. International Journal of Uncertainty, Fuzziness and Knowledge-Based Systems, 12, 791-810.

Xu, Z.S. (2005a). An overview of methods for determining OWA weights. International Journal of Intelligent Systems, 20, 843-865.

Xu, Z.S. (2005b), Deviation measures of linguistic preference relations in group decision making. Omega, 33, 249-254.

Xu, Z.S. (2006). Induced uncertain linguistic OWA operators applied to group decision making. Information Fusion, 7, 231-238.

Xu, Z.S., Chen, J. (2008). Ordered weighted distance measures. Journal of Systems Science and Systems Engineering, 17, 432-445.

Xu, Z.S., Da, Q.L. (2002). The ordered weighted geometric average operators. International Journal of Intelligent Systems, 17, 709-716.

Xu, Y.J., Da, Q.L. (2010). Standard and mean deviation methods for linguistic group decision making and their applications. Expert Systems with Applications, 37, 5905-5912. 
Xu, Y.J., Wang, H.M. (2011). Approaches based on 2-tuple linguistic power aggregation operators for multiple attribute group decision making under linguistic environment. Applied Soft Computing, 11, 3988-3997.

Xu, Z.S., Xia, M. (2011). Distance and similarity measures for hesitant fuzzy sets. Information Sciences, 181, $2128-2138$.

Yager, R.R. (1988). On ordered weighted averaging aggregation operators in multi-criteria decision making. IEEE Transactions on Systems, Man and Cybernetics B, 18, 183-190.

Yager, R.R. (1993). Families of OWA operators. Fuzzy Sets and Systems, 59, 125-148.

Yager, R.R. (2004). Generalized OWA aggregation operators. Fuzzy Optimization and Decision Making, 3, 93-107.

Yager, R.R. (2010). Norms induced from OWA operators. IEEE Transactions on Fuzzy Systems, 18, 57-66.

Zadeh, L.A. (1975). The concept of a linguistic variable and its application to approximate reasoning, Part 1, Information Sciences, 8, 199-249; Part 2, Information Sciences, 8, 301-357; Part 3, Information Sciences, 9, 43-80.

Zeng, S.Z. (2011). Some intuitionistic fuzzy weighted distance measures and their application to group decision making. Group Decision and Negotiation, in press. DOI:10.1007/s10726-011-9262-6.

Zeng, S.Z., Su, W. H. (2011). Intuitionistic fuzzy ordered weighted distance operator. Knowledge-Based Systems, 24, 1224-1232.

Zeng, S.Z., Su, W. H. (2012). Linguistic induced generalized aggregation distance operators and their application to decision making. Economic Computer and Economic Cybernetics Studies and Research, 46, 155-172.

Zhou, L.G., Chen, H.Y. (2010). Generalized ordered weighted logarithm aggregation operators and their applications to group decision making. International Journal of Intelligent Systems, 25, 683-707.

Zhou, L.G., Chen, H.Y. (2011). Continuous generalized OWA operator and its application to decision making. Fuzzy Sets and Systems, 16, 18-34.

Z. Shouzhen graduated from the Tianjin University and obtained the master degree in applied mathematics in 2007. At present, he is studying his in-service doctor of applied statistics at Zhejiang Gongshang University. He has published more than 40 papers in journals, books and conference proceedings including journals such as Statistics Research, Economic Research, Knowledge-Based Systems and Group Decision and Negotiation. His main research fields are aggregation operators, decision making, comprehensive evaluation, and uncertainty. Now he is a full-time lecturer at Zhejiang Wanli University.

T. Baležentis is a specialist at the Lithuanian Institute of Agrarian Economics. He received student scientific paper award (2011) from the Lithuanian Academy of Sciences, as well as the scholarship of the President of the Republic of Lithuania for 2012-2013. Tomas Baležentis has published over 30 peer-reviewed papers on multi-criteria decision making, benchmarking, and quantitative methods.

Z. Chonghui graduated from the Zhejiang Gongshang University and obtained bachelor applied mathematics degree in 2010. At present, he is studying his master degree in statistics at Zhejiang Gongshang University. His main research fields are aggregation operators, decision making, comprehensive evaluation, and uncertainty. 


\title{
Sutvarkytojo svertinio vidurkio operatoriumi ir atstumo funkcijomis pagristas metodas daugiakriteriniam sprendimu prièmimui naudojantis dvinariais lingvistiniais kintamaisiais
}

\author{
Shouzhen ZENG, Tomas BALEŽENTIS, Chonghui ZHANG
}

Šiame straipsnyje pristatomas metodas, skirtas daugiakriteriniam sprendimu prièmimui remiantis dvinariais kintamaisiais išreikšta lingvistine informacija, t.y. apibendrintasis dvinario lingvistinio sutvarkytojo svertinio vidurkio atstumo (2LGOWAD) operatorius. Šis operatorius yra sutvarkytojo svertinio vidurkio (OWA) plètinys, leidžiantis atsižvelgti ị apibendrintus vidurkio matus, atstumo funkcijas ir neapibrěžtą informaciją, išreikštą dvinariais lingvistiniais kintamaisiais. Atskiri 2LGOWAD operatoriaus atvejai yra: dvinaris lingvistinis maksimalus atstumas, dvinaris lingvistinis minimalus atstumas, normalizuotas dvinaris lingvistinis Hamming atstumas, svertinis dvinaris lingvistinis Hamming atstumas, normalizuotas dvinaris lingvistinis Euklido atstumas, svertinis dvinaris lingvistinis Euklido atstumas, dvinaris lingvistinis sutvarkytasis svertinis vidutinis atstumas, dvinaris lingvistinis sutvarkytasis Euklidos vertinis vidutinis atstumas. Straipsnyje aptariamos pagrindinės šių operatoriu ypatybės ir taikant kvazi-vidurkị apibendrinamas 2LGOWAD operatorius. Pateikiamas naujujų operatorių taikymo sprendimų prièmimo (investavimo strategijos pasirinkimo) procese pavyzdys. 
